\title{
Principal Component Analysis of Changes due to Water Stress for Some Osmolytes, Pigments and Antioxidant Enzymes in Gmelina arborea Robx. Leaves from Trees Planted in Northern Colombia
}

\author{
Sandra C. Crespo, Andres L. Moreno-Chacón, Andrea Rojas and Luz M. Melgarejo* \\ Plant Physiology and Biochemistry Research Laboratory, Biology Department, \\ Universidad Nacional de Colombia, Ciudad Universitaria, Bogotá, Colombia
}

\begin{abstract}
Gmelina arborea é uma espécie de alto impacto econômico devido a vantagens como árvore madeireira de rápido crescimento. A G. arborea é plantada na costa norte da Colômbia, especialmente nas planícies secas do Caribe. No entanto, condições de déficit hídrico a que estão periodicamente submetidos, gera perdas nas plantações. Neste estudo mediram se a atividade da catalase, peroxidase e ascorbato peroxidase, assim como o conteúdo de açúcares totais, açúcares redutores, proline, carotenóides, clorofila A, B em folhas coletadas em três estações climáticas diferentes. Um estudo de análises de componentes principais mostrou que o comportamento das variáveis medidas depende tanto da idade quanto do tempo de amostragem, além de uma correlação inversa entre as variáveis de clorofila A, B e total e as outras variáveis medidas.
\end{abstract}

Gmelina arborea is a tree having great economic impact due to its advantages as a fast-growing timber tree. G. arborea is currently being planted on the North Coast of Colombia, especially on the dry plains near the Caribbean. However, the stress conditions produced by drought to which they are periodically subjected lead to plantation loss. This study was thus aimed at measuring catalase, peroxidase and ascorbate peroxidase activities as well as total sugar, reducing sugar, proline, carotenoids, chlorophyll A, B and total chlorophyll content in G. arborea leaves sampled during three seasons of the year. Principal component analysis showed that the measured variables had patterns depending on age and season, in addition to an inverse correlation between chlorophyll A, B and total chlorophyll and the other measured variables.

Keywords: principal component analysis, water stress, oxidative stress, antioxidant system

\section{Introduction}

Plants are continuously exposed to unfavorable environmental conditions such as extreme temperatures and low water availability. Water deficit is most common as it results from reduced soil water availability and hot/dry weather conditions, causing continuous loss of water through transpiration and evaporation and thereby resulting in profound effects on plant growth, yield and productivity. Some physiological changes can be made to counteract such harmful effects arising from this event, such as increasing abscisic acid levels, stomatal closure, changes in cell osmolarity and increased enzymatic and non-enzymatic antioxidant concentration. ${ }^{1}$

Water deficit also results in important effects on photosynthesis due to minimizing carbon dioxide supply

*e-mail: 1mmelgarejom@unal.edu.co by the closure of stomata. However, when there is a gradual increase in deficit, acclimation may occur to minimize these effects due to osmotic adjustment, thereby enabling the chloroplasts to maintain volume by accumulating certain constituents in the stroma, as in the case of proline and some sugars. ${ }^{2,3}$ However, severe or long periods of low water availability can damage the photosynthetic machinery. Irradiance plays a vital role in changes taking place within a plant during water stress since the photosynthetic rate decreases and high irradiance produce excess energy resulting in the production of reactive oxygen species (ROS). ${ }^{1}$

ROS are molecules having high reactivity and occur during normal cell operation as part of the redox balance to activate and deactivate some protein activities. ${ }^{4}$ Its production arises from electron transfer to an oxygen molecule such as superoxide radical anion, hydrogen peroxide and hydroxyl radical, or spin alteration, as in 
the case of singlet oxygen. ${ }^{5}$ ROS also act as an alarm for imbalances in the plant, activating signaling cascades triggering short-term physiological responses or long-term transcriptional ones. ${ }^{6}$ Furthermore, when ROS are produced in large quantities they can be responsible for different types of cell damage, such as lipid peroxidation, proteins oxidation and even DNA damage.,

Increased ROS levels are caused by several types of environmental stress, creating what is known as oxidative stress during which ROS produce an imbalance in the redox state of the cell because they react with a large number of structural molecules and so produce significant damage to cell function. ${ }^{8}$ Two types of mechanism respond to such altered redox states: a non-enzymatic system (consisting of ascorbic acid, polyphenols, chalcones, tocopherols, anthocyanins, carotenoids and glutathione) and enzyme systems. Such enzymes can be classified into two broad groups: (i) enzymes using $\mathrm{H}_{2} \mathrm{O}_{2}$ as substrate or cofactor which are able to remove/neutralize $\mathrm{H}_{2} \mathrm{O}_{2}$ directly (i.e. catalase (CAT), ${ }^{9}$ ascorbate peroxidase (APX), ${ }^{10}$ glutathione peroxidase (GPOD), ${ }_{11}^{11}$ peroxyredoxin (PRX), ${ }^{12}$ type 3 peroxidase (POD) $)^{13}$ and (ii) enzymes using different ROS as substrate or cofactor (i.e. superoxide dismutase (SOD) ${ }^{14}$ and glutathione reductase (GR)).

Catalase (CAT) (EC. 1.11.1.6) is located in peroxisomes and is responsible for controlling the flow of $\mathrm{H}_{2} \mathrm{O}_{2}$ by catalyzing its disproportion to water and oxygen. It is usually a tetramer wherein each subunit contains a heme group..$^{15}$ Peroxidases (POD) (EC. 1.11.1.7) are oxydoreductase metalloenzyme series reducing organic and inorganic peroxides into their corresponding alcohols by using a cysteine active site. ${ }^{16}$ They are located in the cytoplasm in soluble form and are bound through ionic or covalent bonds on the cell wall. ${ }^{17}$ Ascorbate peroxidase (APX) (EC. 1.11.1.11) is one of the most important enzymes in hydrogen peroxide and nitrogen detoxification in chloroplasts; it participates in the glutathione-ascorbate cycle. This enzyme uses $\mathrm{H}_{2} \mathrm{O}_{2}$ as substrate together with ascorbate anion to generate monodehydroascorbate (MDA) and dehydroascorbate (DHA). ${ }^{18,19}$

G. arborea is a native South-eastern Asia specie and has been introduced into South America. It belongs to the family Verbenaceae and is characterized by rapid growth and it reaches up to $30 \mathrm{~m}$ in height and $100 \mathrm{~cm}$ in diameter. This species is recognized for its potential in ecosystem recovery and that of the environment. ${ }^{20,21} G$. arborea has been planted on the Northern Coast of Colombia, especially on the dry plains near the Caribbean. However, the water deficit conditions to which they are periodically subjected cause plantation loss, increased costs due to re-seeding and the need for greater use of irrigation water.
This study was aimed at determining total sugar, reducing sugars, proline, carotenoids, chlorophyll A, B and total chlorophyll and total protein content as well as catalase, peroxidase and ascorbate peroxidase activities during three climatic seasons in the leaves of G. arborea Robx trees planted in northern Colombia.

\section{Experimental}

\section{Apparatus}

A SmartSpec Plus spectrophotometer (Bio-Rad) was used for taking spectrophotometric measurements for determining chlorophyll A, B, total chlorophyll, carotenoids and proline content and determining catalase, peroxidase and ascorbate peroxidase activities. An ImarkMicroplate Absorbance Reader was used for taking total and reducing sugars and total protein spectrophotometric measurements.

\section{Reagents and solutions}

All chemicals were analytical-reagent grade or better. All solutions and dilutions were prepared with ultrapure water (Thermo Scientific Barnstead RO, Reverse Osmosis System).

\section{Samples}

The leaf tissue samples were taken from $G$. arborea Robx clone 79 from Pizano SA Monterrey Forestal Ltda plantation in Zambrano (Bolívar), northern Colombia; they were collected during the three study periods: rainy season (September-October), transition to dry season (December) and dry season (February-April). Three-hour sampling $(8,10$ and $12 \mathrm{~h}$ ) and three ages (seedling, juvenile and adult) were used. The seedlings were sown in the field on August $6^{\text {th }} 2008$, the samplings (juvenile trees) on October $10^{\text {th }} 2007$ and adult trees on May $25^{\text {th }} 2004$.

The leaves were collected from the mid-section of three trees per age and stored at $-10{ }^{\circ} \mathrm{C}$; they were then macerated with liquid $\mathrm{N}_{2}$ to a fine powder which was kept at $-10{ }^{\circ} \mathrm{C}$ until final processing. Climatic data: maximum temperature and rainfall were obtained from the IDEAM weather station in Monterrey Forestall (Figure S1).

\section{Analytical determination}

Material was macerated in triplicate using the following determination: catalase (CAT) activity ( $\mu \mathrm{g}$ mol $\mathrm{H}_{2} \mathrm{O}_{2} \mathrm{~min}^{-1} \mathrm{mg}^{-1}$ protein) according to Aebi, ${ }^{22}$ peroxidase (POD) activity $\left(\Delta \mathrm{A}_{436 \mathrm{~mm}} \mathrm{~min}^{-1} \mathrm{mg}^{-1}\right.$ protein) 
according to Kireyko et al. ${ }^{23}$ ascorbate peroxidase (APX) activity (nmol oxidized ascorbate $\mathrm{min}^{-1} \mathrm{mg}^{-1}$ protein) according to Nakano and Asada, ${ }^{24}$ protein content according to Bradford ( $\mathrm{mg} \mathrm{g}^{-1}$ plant material), ${ }^{25}$ carotenoids and chlorophylls A, B and total chlorophyll $\left(\mathrm{mg} \mathrm{g}^{-1}\right.$ plant material) according to Lichtenthaler, ${ }^{26}$ total sugar content ( $\mathrm{mg} \mathrm{g}^{-1}$ plant material) according to DuBois et al. ${ }^{27}$ reducing sugar content ( $\mathrm{mg} \mathrm{g}^{-1}$ plant material) according to Nelson and Somogyi, ${ }^{28,29}$ and proline content $\left(\mu \mathrm{g} \mathrm{g}^{-1}\right.$ plant material) according to Bates et al..$^{30}$

All methods were standardized in the Plant Physiology and Biochemistry Research Laboratory of the Universidad Nacional de Colombia and details can be found in the Plant Physiology Experiments manual. ${ }^{31}$

\section{Data analysis}

A data matrix containing 27 rows (samples) and 13 columns (variables) was built. The pattern recognition technique used in this work was principal component analysis (PCA): this is a procedure that allows exploring the data structure, the relationship between objects, the relationship between objects and variables and overall correlation of the variables. ${ }^{32}$ MATLAB 7.9.0529 (R2009b) for Windows (MathWorks) was used for PCA.

\section{Results}

Table S1 shows the results for determining total and reducing sugars, proline, chlorophyll A, B, total chlorophyll, carotenoids, total protein and catalase, peroxidase and ascorbate peroxidase activity.

Total sugar, reducing sugar, proline, carotenoids, chlorophyll content and CAT, POD and APX activity were used as descriptors for principal component analysis; this analysis was carried out with auto-scaling data.

It was found that the first component accounted for $64.21 \%$ of variance and the second one to $14.11 \%$ of variance. The loading plot (Figure 1) showed that principal component $\mathrm{PC} 1$ gave chlorophyll $\mathrm{A}$, chlorophyll $\mathrm{B}$ and total chlorophyll as dominant variable, appearing to be negative PC1 values. Proline, catalase, carotenoids, season, peroxidase and reducing sugars appeared to be positive values for $\mathrm{PC} 1$, so there was an inverse correlation between chlorophyll A, B and total chlorophyll compared to the other variables. Dominant variables for the second component (PC2) were chlorophylls A and B, total chlorophyll and total protein; they displayed positive PC2 values. It is worth noting that time was not a relevant variable for either component (PC1 and PC2), however, time appeared to have negative values for the third component (not shown) which

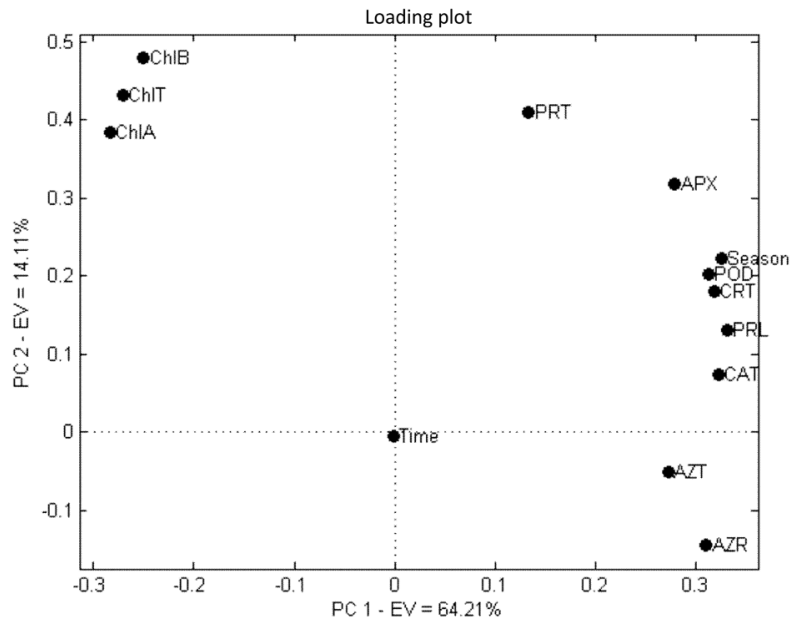

Figure 1. Loading plot for principal component analysis.

explained $7.73 \%$ of variance, having an inverse correlation with protein.

The score plot (Figure 2) clearly shows the presence of three different groups on the $\mathrm{PC} 1$ axis corresponding to sampling time. PC2 shows three different age groups. These results showed that the measured variables had a pattern dependent on both season and age.

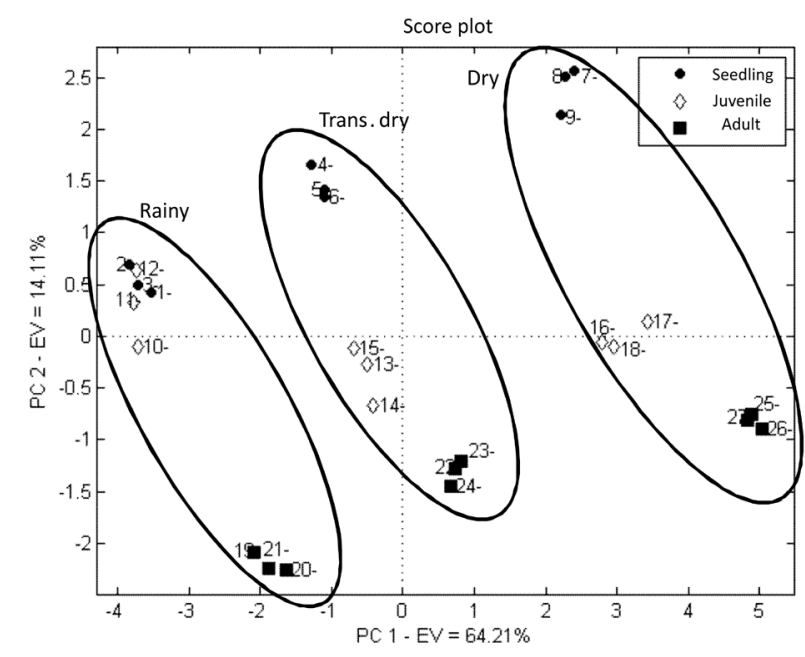

Figure 2. Score plot for principal component analysis.

Simultaneous analysis of the two charts showed that adult specimens had a direct correlation with sugar content; seedlings were correlated with protein, carotenoids, chlorophyll A, B and total chlorophyll content; while juveniles occupied an intermediate position.

\section{Discussion}

Water stress leads to reduced cell water content, in turn leading to loss of lipid bilayer integrity ending in loss of function, selectivity, disruption and affects the activity of 
some enzymes. Moreover, in the event of stress-related drought, there are three types of signals or response which are designed to compensate for water loss. First, conditions are maintained which produce efficient osmosis water use (ABA production) and maintain homeostasis under stress by an increase in molecules consistent with sugar, polyol, proline cell structures. Secondly, ROS are controlled by enzymatic and molecular systems and, thirdly, cell division is coordinated to meet the requirements of plants under stress. ${ }^{33}$

The present study provided evidence that $G$. arborea increased sugar and proline content during the dry season compared to rainy periods and transition to dry season (Table S1) as an osmoregulatory response to prevent cell dehydration. This behavior has been reported in other studies of plants subjected to water stress in controlled conditions ${ }^{34,35}$ or in field conditions ${ }^{36}$ (as our case study). This response occurs because plants tend to compensate for cellular drought stress through osmoregulatory production of proline, glutamate, glycine betaine, carnitine, mannitol, sorbitol, fructans, polyols, trehalose, sucrose, some hexoses and oligosaccharides. These molecules help maintain a hydrated state and promote resistance to dehydration by maintaining leaf turgor. ${ }^{37-39}$ It is assumed that sugars also play a role in stabilizing some macromolecules and cellular structures ${ }^{39}$ are involved in controlling ROS during water stress ${ }^{40}$ and assist in maintaining certain physiological functions, such as partial stomatal opening, photosynthesis and cell expansion. ${ }^{41}$ Moreover, it has been proposed that proline affects some effectors involved in the expression of genes related to plant tolerance to different types of stress. ${ }^{2,42}$ It also has a stabilizing effect on protein and membrane structure, is an inducer of osmotic stress-related genes ${ }^{43}$ and is a source of readily-available carbon and nitrogen in cell re-hydration. ${ }^{44}$ This study (like many others) has shown that there is an increase in total soluble sugars and proline during water stress conditions $s^{1,2,45,46}$ as a strategy for preventing drying out and damage from oxidative stress.

Increased carotenoid content is another response to energy dissipation level and carbon and nitrogen content regulation to increase the excess energy of the receptor molecules and use chlorophyll as a source of carbon and nitrogen. ${ }^{47}$ There is perfect coordination between lightinduced electron transfer in thylakoid membrane and carbon dioxide fixation by the Calvin cycle in the stroma in natural conditions; however, stress results in an imbalance which triggers ROS formation that damages the photosynthetic apparatus. ${ }^{48}$

The $G$. arborea study reported here found decreased chlorophyll A, B and total chlorophyll content and an increase in carotenoids during the dry season compared to the rainy and transition to dry season. Pigment study is important from an ecophysiological viewpoint as it provides information about productivity, stress and degradative events and limiting nutrients. Alterations in photosynthetic pigment composition may be related to photoacclimation. ${ }^{49}$ High irradiance acclimated cells may contain high concentrations of carotenoids in relation to chlorophyll A. Yellow-orange carotenoids are associated with membrane-embedded proteins within chloroplasts where they interact with acceptor molecules and carriers. They have a protection-inducing photoxidative role against damage to the photosynthetic apparatus, dissipating excess light absorbed by pigment antenna. ${ }^{50,51}$ Similar results have been reported for other plants subjected to water stress. Nayyar and Gupta ${ }^{52}$ found a significant decrease in chlorophyll content in Triticum aestivum and Zea mays plants subjected to water stress, and Jung ${ }^{53}$ found a decrease in chlorophyll content in mature Arabidopsis thaliana leaves subjected to water stress; however, no changes were found in carotenoids content compared to control.

The results of CAT, POD and APX activities in $G$. arborea showed significant increase during the dry season compared to the rainy season and transition to dry season. Other studies have reported similar behaviors: Bai et al..$^{54}$ found increased SOD activity during severe water stress treatment in maize plants (Zea mays L.) and increased POD activity when subjected to moderate stress and severe stress. Ozkur et al. ${ }^{55}$ noted significant increases in SOD, POD and CAT activities in leaves from caper (Capparis ovate Def.) plants subjected to water stress induced by adding polyethylene glycol (PEG). Nayyar and Gupta ${ }^{52}$ studied the effect of low, moderate and severe water stress on $\mathrm{C} 3$ (Triticum aestivum) and $\mathrm{C} 4$ plants (Zea mays), finding that leaves' CAT and APX activity was greater for moderate stress in both types of plant.

\section{Conclusions}

Principal component analysis clearly established the presence of three groups corresponding to season (rainy season, transition to dry season and dry season) and three age-related groups (seedling, juvenile and adult). Increased osmoregulatory compound content and activity of the enzymes being studied (forming part of antioxidant enzymes) indicated that $G$. arborea exhibited oxidative stress due to water stress during the dry season. It showed that the plant responded to such oxidative stress by increasing the activity of particular enzymes catalyzing the decomposition of chemical ROS species which are dangerous for cells and synthesizing compounds stabilizing cell structures and preventing desiccation. 


\section{Supplementary Information}

Supplementary data (Table S1 and data concerning climate Figure S1) are available free of charge at http://jbcs.sbq.org.br as pdf file.

\section{Acknowledgments}

We would like to thank the Colombian Ministry of Agriculture and Rural Development, the Universidad Nacional de Colombia, Pizano SA Monterrey plantation forestry (Zambrano, Bolivar), Miguel Rodriguez (for funding and logistical support) and Danny Rodriguez Lopez for advice on statistical analysis.

\section{References}

1. Smirnoff, N.; New Phytologist 1993, 125, 27.

2. Kavi Kishor, P. B.; Sangam, S.; Amrutha, R. N.; Laxmi, P. S.; Naidu, K. R.; Rao, K. R. S. S.; Sreenath, R.; Reddy, K. J.; Theriappan, P.; Sreenivasulu, N.; Curr. Sci. 2005, 88, 424.

3. Chen, T. H.; Murata, N.; Curr. Opin. Plant Biol. 2002, 5, 250.

4. Wormuth, D.; Heiber, I.; Shaikali, J.; Kandlbinder, A.; Baier, M.; Dietz, K. J.; J. Biotechnol. 2007, 129, 229.

5. Sweetlove, L. J.; Møller, I. M.; Adv. Bot. Res. 2009, 52, 1.

6. D’Autréaux, B.; Toledano, M. B.; Nat. Rev. Mol. Cell Biol. 2007, 8, 813 .

7. Tambussi, E. A.; Bartoli, C. G.; Beltrano, J.; Guiamet, J. J.; Araus, J. L.; Physiol. Plant. 2000, 108, 398.

8. Møller, I. M.; Jesen, P. E.; Hasson, A.; Annu. Rev. Plant Biol. 2007, 58, 459.

9. Vandenabeele, S.; Vanderauwera, S.; Vuylsteke, M.; Rombauts, S.; Langebartels, C.; Seidlitz, H. K.; Zabeau, M.; Montagu, V. M.; Inzé, D.; Breusegem, V. F.; Plant J. 2004, 39, 45.

10. Mittler, R.; Vanderauwera, S.; Gollery, M.; Breusegem, V. F.; Trends Plant Sci. 2004, 9, 490.

11. Rodriguez, M. M. A.; Maurer, A.; Rodriguez, H. A.; Gustafson, J. P.; Plant J. 2003, 36, 602.

12. Dietz, K. J.; Annu. Rev. Plant Biol. 2003, 54, 93.

13. Tognolli, M.; Penel, C.; Greppin, H.; Simon, P.; Gene 2002, 288,129

14. Kliebenstein, D. J.; Monde, R. A.; Last, R. L.; Plant Physiol. 1998, 118, 637.

15. Switala, J.;Loewen, P.C.; Arch. Biochem. Biophys. 2002, 401, 145.

16. Herrero, E.; Ros, J.; Bellí, G.; Cabiscol, E.; Biochim. Biophys. Acta, Gen. Subj. 2008, 1780, 1217.

17. Grison, R.; Pilet, P. E.; J. Plant Physiol. 1985, 118, 189.

18. Asada, K.; Annu. Rev. Plant Physiol. Plant Mol. Biol. 1999, 50, 601.

19. Tausz, M.; Šircelj, H.; Grill, D.; J. Exp. Bot. 2004, 55, 1955.

20. Rodríguez, R. F.; Arias, A. D.; Moya, R. R.; Meza, M. A.;
Murillo, G. O.; Arguedas, G. M.; Manual para Productores de Melina Gmelina Arborea en Costa Rica; Centro de Investigación en Integración Bosque Industria de la Escuela de Ingeniería Forestal del Instituto Tecnológico de Costa Rica: Cartago, 2004, http://www.sirefor.go.cr/Documentos/ Especies_plantaciones/MELINA/Manual\%20para\%201os\% 20productores\%20de\%20melina.pdf, accessed in February 2011.

21. Obregón, S. C.; Gmelina Arborea. Versatilidad, Renovación y Productividad Sostenible para el Futuro; Revista El Mueble y La Madera: Bogotá D. C., 2005, http://www.revista-mm.com/ ediciones/rev50/especie.pdf, accessed in March 2011.

22. Aebi, H. In Methods of Enzymatic Analysis; Bergmeyer, H. U., ed.; Academic Press Inc: New York., 1974.

23. Kireyko, A. V.; Veselova, I. A.; Shekhovtsova, T. N.; Russ. J. Bioorg. Chem. 2006, 32, 71.

24. Nakano, Y.; Asada, K.; Plant Cell Physiol. 1987, 28, 131.

25. Bradford, M. M.; Anal. Biochem. 1976, 72, 248.

26. Lichtenthaler, H. K. In Methods in Enzymology, Colowick, S. P.; Kaplan, N. O., eds.; Academic Press: New York, 1987.

27. DuBois, M.; Gilles, K. A.; Hamilton, J. K.; Rebers, P. A.; Smith, F.; Anal. Chem. 1956, 28, 350.

28. Nelson, N.; J. Biol. Chem. 1944, 153, 375.

29. Somogyi, M.; J. Biol. Chem. 1952, 195, 19.

30. Bates, L. S.; Waldren, R. P.; Teare, I. D.; Plant Soil 1973, 39, 205.

31. Melgarejo, L. M.; Romero, M.; Hernández, S.; Barrera, J.; Solarte, M. E.; Suárez, D.; Pérez, L. V.; Rojas, A.; Cruz, M.; Moreno, A. L.; Crespo, S. C.; Pérez, W. H.; Experimentos en Fisiología Vegetal; Universidad Nacional de Colombia: Bogotá, 2010.

32. Beebe, K. R.; Pell, R. J.; Seasholtz, M. B.; Chemometrics: a Practical Guide; Wiley: New York, 1998.

33. Liu, J.; Zhu, J. K.; Science 1998, 280, 1943.

34. Liu, F.; Andersen, M. N.; Jacobsen, S. E.; Jensen, C. R.; Environ. Exp. Botany 2005, 54, 33.

35. García, A.; Dorado, M.; Pérez, I.; Montilla, E.; Interciencia: Revista de Ciencia y Tecnología de América 2010, 35, 47.

36. Munné-Bosch, S.; Peñuelas, J.; Plant Sci. 2004, 166, 1105.

37. Hoekstra, F. A.; Golovina, E. A.; Buitink, J.; Trends Plant Sci. 2001, 6, 431.

38. Ramanjulu, S.; Bartels, D.; Plant Cell Environ. 2002, 25, 141.

39. Mahajan, S.; Tuteja, N.; Arch. Biochem. Biophys. 2005, 444, 139.

40. Zhu, J. K.; Trends Plant Sci. 2001, 6, 66.

41. Lawlor, D. W.; Cornic, G.; Plant Cell Environ. 2002, 25, 275.

42. Yoshiba, Y.; Kiyosue, T.; Nakashima, K.; Kazuko, Y. S.; Shinozaki, K.; Plant Cell Physiol. 1997, 38, 1095.

43. Iyer, S.; Caplan, A.; Plant Physiol. 1998, 116, 203.

44. Brugière, N.; Dubois, F.; Limami, A. M.; Lelandais, M.; Roux, Y.; Sangwan, R. S.; Hirel, B.; Plant Cell 1999, 11, 1995. 
45. Abebe, T.; Guenzi, A. C.; Martin, B.; Cushman, J. C.; Plant Physiol. 2003, 131, 1748.

46. Avendaño, A. C. H.; Trejo, L. C.; López, C. C.; Molina, G. J. D.; Santacruz, V. A.; Castillo, G. F.; Interciencia: Revista de Ciencia y Tecnología de América 2005, 30, 560.

47. Tanaka, R.; Tanaka, A.; Annu. Rev. Plant Biol. 2007, 58, 321.

48. Shanker, D. R. In Handbook of Photosynthesis; Pessarakli, M., ed.; CRC Press: New York, 2005.

49. Richardson, A. D.; Duigan, S. P.; Berlyn, G. P.; New Phytologist 2002, 153, 185.

50. Lichtenthaler, H. K.; Buschmann, C. In Current Protocols in Food Analytical Chemistry; John Wiley \& Sons Inc.: New York, 2001.
51. Demmig-Adams, B.; Adams, W. W.; Trends Plant Sci. 1996, 1, 21.

52. Nayyar, H.; Gupta, D.; Environ. Exp. Botany 2006, 58, 106.

53. Jung, S.; Plant Sci. 2004, 166, 459.

54. Bai, L. P.; Sui, F. G.; Ge, T. D.; Sun, Z. H.; Lu, Y. Y.; Zhou, G. S.; Pedosphere 2006, 16, 326.

55. Ozkur, O.; Ozdemir, F.; Bor, M.; Turkan, I.; Environ. Exp. Botany 2009, 66, 487.

Submitted: April 11, 2011

Published online: August 30, 2001 


\title{
Principal Component Analysis of Changes due to Water Stress for Some Osmolytes, Pigments and Antioxidant Enzymes in Gmelina arborea Robx. Leaves from Trees Planted in Northern Colombia
}

\author{
Sandra C. Crespo, Andres L. Moreno-Chacón, Andrea Rojas and Luz M. Melgarejo* \\ Plant Physiology and Biochemistry Research Laboratory, Biology Department, \\ Universidad Nacional de Colombia, Ciudad Universitaria, Bogotá, Colombia
}

Climate

Figure $\mathrm{S} 1$ shows the maximum temperature $\left(\mathrm{T}_{\max }\right)$ and rainfall pattern during the study period. Rainfall during September and October had similar, high values. The values recorded during November were because of La Niña. Rainfall became minimal during December and the dry season began in January.

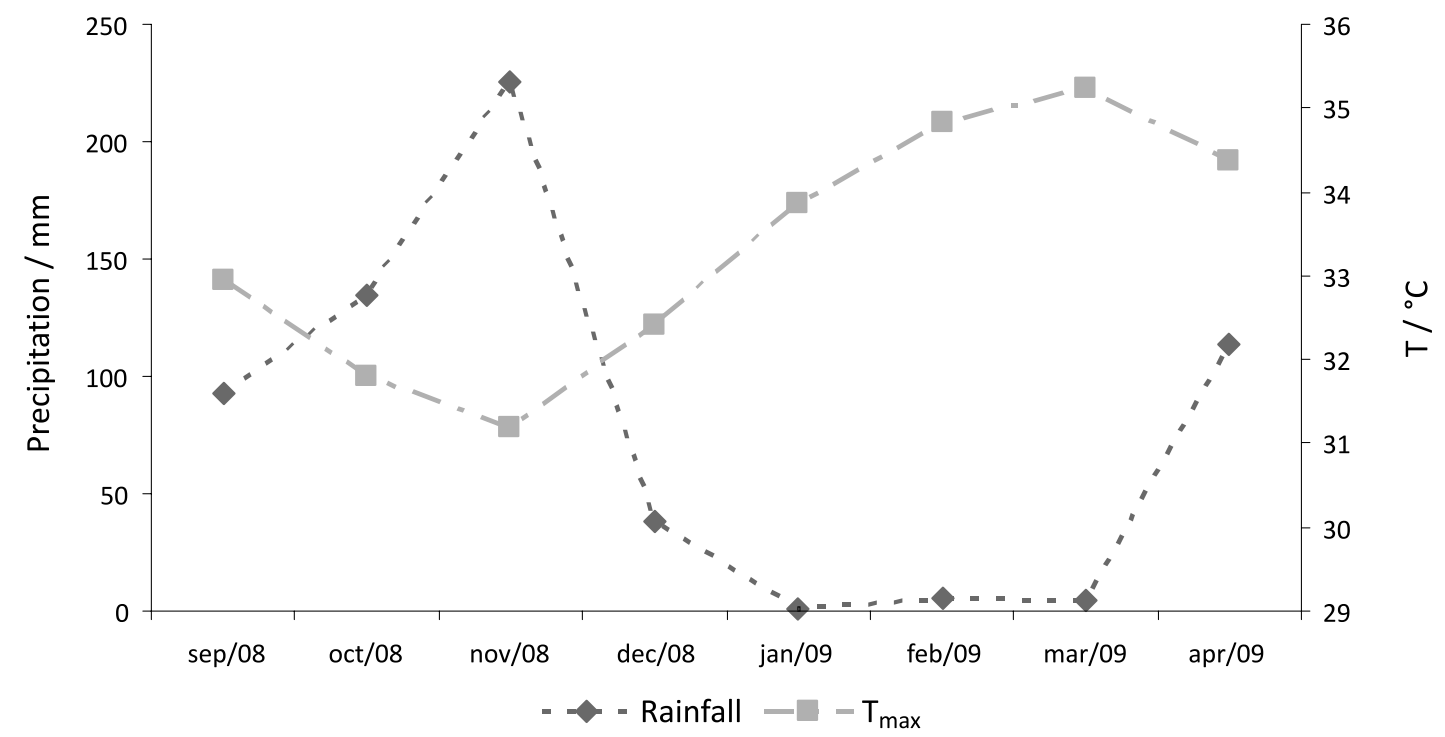

Figure S1. Average daily maximum temperature $\left(\mathrm{T}_{\max }\right)$ and rainfall from September 2008 to April 2009. 


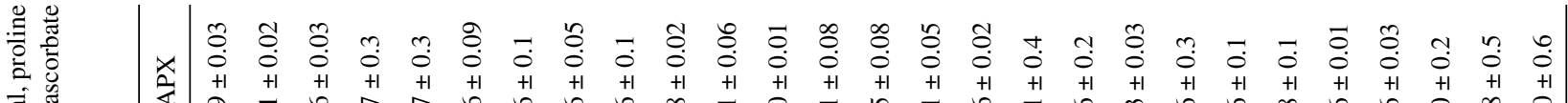

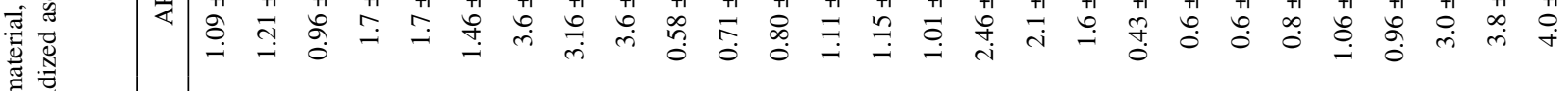

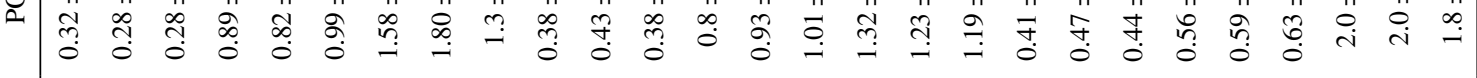

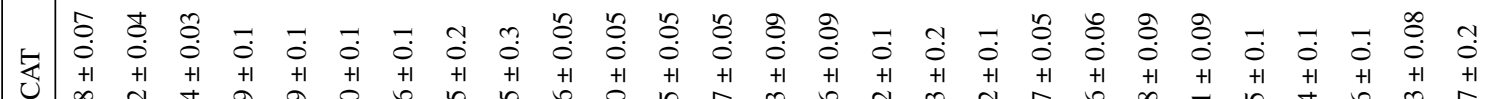

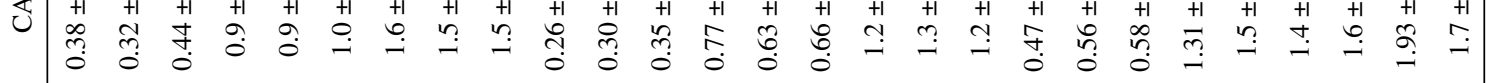

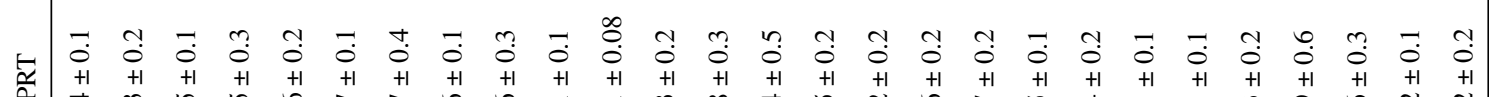

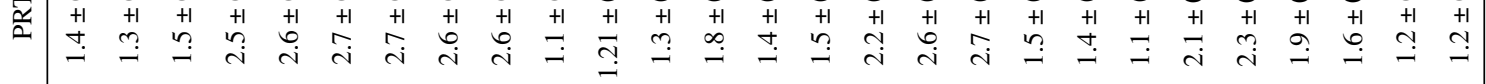


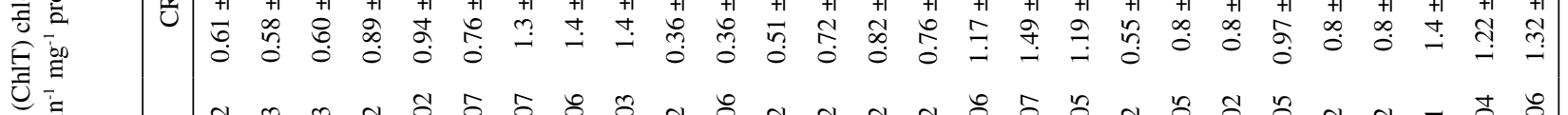

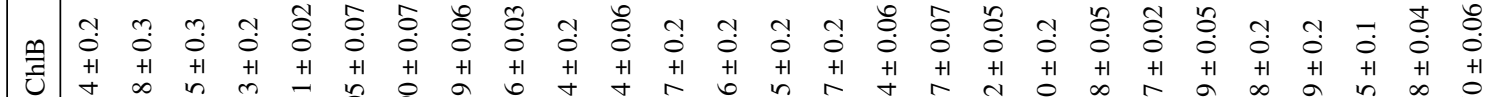
(

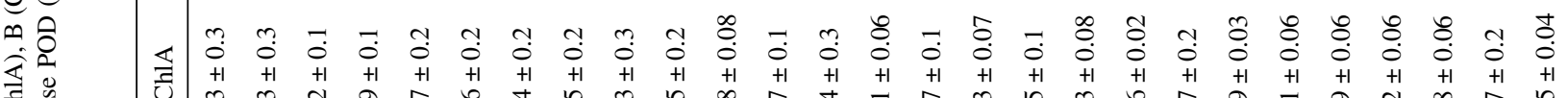

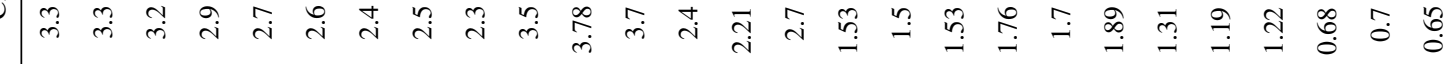

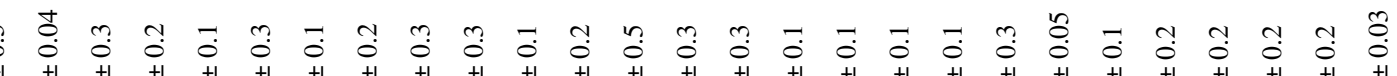

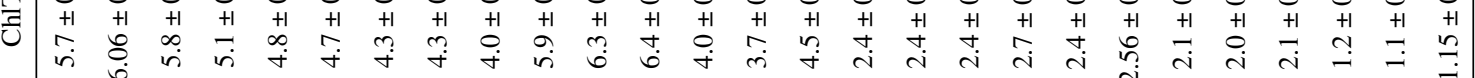
के $\Xi$ bo 